\title{
Faktor-Faktor yang Berhubungan dengan Kekurangan Energi Kronis (KEK) pada Ibu Hamil di Wilayah Kerja Puskesmas Tosa Kota Tidore Kepulauan Tahun 2018
}

\author{
Umar Latif ${ }^{1}$, Agustin Rahayu ${ }^{1}$, dan Suryani Mansyur ${ }^{1 凶}$ \\ 1 Universitas Muhammadiyah Maluku Utara. Ternate. Indonesia, \\ Email : agustinyayu21@gmail.com,ryanimansyur@gmail.com \\ $\triangle$ \\ Korespondensi : Agustin Rahayu, Universitas Muhammadiyah Maluku Utara. Ternate, \\ Email : agustinyayu21@gmail.com
}

\begin{abstract}
ABSTRAK.
Kekurangan energi kronis (KEK) merupakan kondisi yang disebabkan karena adanya ketidakseimbangan asupan gizi antara energi dan protein, sehingga zat gizi yang dibutuhkan tubuh tidak tercukupi. Ibu hamil yang menderita Kekurangan Energi Kronis (KEK) mempunyai resiko kematian ibu mendadak pada masa perinatal atau resiko melahirkan bayi dengan berat bayi lahir rendah. Dari data yang diperoleh dari Dinas Kesehatan Kota Tidore Kepulauan Prevalensi KEK tertinggi berada di Puskesmas Tosa dari tahun 2015-2017 yaitu sebanyak 68 Kasus (44\%) sedangkan yang terendah prevalensi KEK berada di Puskesmas Soasio yaitu sebanyak 22 kasus dari tahun 2015-2017. Penelitian ini bertujuan untuk mengetahui faktorfaktor yang berhubungan dengan kekurangan energi kronis (KEK) pada ibu hamil di Wilayah Kerja Puskesmas Tosa Kota Tidore Kepulauan Tahun 2018. Jenis penelitian yang digunakan adalah kuantitaf melalui pendekatan observasional dengan rancangan Cross Sectional Study dan menggunakanTotal sampling dengan jumlah 54 sampel. Pengumpulan data dilakukan dengan cara pengisian kuesioner secara langsung, pengukuran lingkar lengan (LILA) dan recall 2x24 jam kepada responden, sedangkan penyajian data dalam bentuk tabel distribusi frekuensi, selanjutnya untuk mengetahui faktor-faktor yang berhubungan dengan kekurangan energi kronis (KEK) dilakukan dengan uji Chi Square. Hasil penelitian menunjukkan bahwa asupan energi dan pendapatan keluarga berpengaruh signifikan dengan KEK pada ibu hamil dengan nilai $P$ yaitu $p=0,01$ dan $p=0,00$ kurang dari 0,05 sedangkan asupan protein $(p=0,29)$, lemak $(p=0,05)$, pengetahuan $(p=0,32)$, usia ibu hamil $(p=1,00)$, dan jarak kelahiran $(p=0,63)$ tidak berhubungan dengan KEK pada ibu hamil.
\end{abstract}

\section{Keywords: KEK, Kurang Energi Kronik, Ibu hamil}

\section{PENDAHULUAN}

Status gizi ibu hamil merupakan salah satu indikator dalam mengukur status gizi masyarakat. Jika asupan gizi untuk ibu hamil dari makanan tidak seimbang dengan kebutuhan tubuh maka akan terjadi defisiensi zat gizi. Kehamilan menyebabkan meningkatnya metabolisme energi. Karena itu, kebutuhan energi dan zat gizi lainnya meningkat selama kehamilan. Peningkatan energi dan zat gizi tersebut diperlukan untuk pertumbuhan dan perkembangan janin, pertambahan besarnya organ kandungan, serta perubahan komposisi dan metabolisme tubuh ibu. Sehingga kekurangan zat gizi tertentu yang diperlukan saat hamil dapat menyebabkan janin tumbuh tidak sempurna (Rahmaniar dkk, 2013).

Kekurangan Energi Kronis (KEK) adalah akibat dari ketidakseimbangan antara asupan untuk pemenuhan dan pengeluaran energi. Tidak tersedianya pangan secara musiman atau secara kronis ditingkat rumah tangga, distribusi makanan di dalam rumah tangga yang tidak proporsional dan minimnya pengetahuan ibu tentang konsumsi makanan saat hamil dapat terjadinya Kekurangan Energi Kronis (KEK). Selain itu, beberapa hal penting yang berkaitan dengan status gizi seorang ibu adalah kehamilan ibu berusia muda, kehamilan dengan jarak yang pendek dengan kehamilan sebelumnya, serta kehamilan pada usia tua juga diduga berkaitan dengan Kurang Energi Kronis (KEK).

Faktor-faktor yang mempengaruhi KEK antara lain adalah jumlah asupan energi, umur, jarak kelahiran, pengetahuan ibu tentang gizi dan pendapatan keluarga. Kebutuhan makanan bagi ibu hamil lebih banyak dari pada kebutuhan wanita yang tidak hamil, Semakin muda dan semakin tua umur 
seseorang ibu yang sedang hamil akan berpengaruh terhadap kebutuhan gizi yang diperlukan, Pemilihan makanan dan kebiasaan diet dipengaruhi oleh pengetahuan, tentang nutrisi melandasi pemilihan makanan. Pendapatan merupakan faktor yang menentukan kualitas dan kuantitas makanan. (Apriyanti, 2011)

Prevalensi Kekurangan Energi Kronis (KEK) di Negara-negara berkembang seperti Banglades, India, Indonesia, Myanmar, Nepal, Srilanka dan Thailand adalah 15-47\%. Adapun negara yang mengalami prevalensi tertinggi adalah Banglades yaitu 47\% sedangkan Indonesia menjadi urutan ke 4 terbesar setelah India dengan prevalensi 35,5\% dan yang paling rendah adalah Thailand dengan prevalensi 15-25\% (WHO, 2010)

Proporsi Ibu hamil Kekurangan Energi Kronis (KEK) di Indonesia berdasarkan Riset Kesehatan Dasar (RISKESDAS 2013) mengalami peningkatan yaitu pada tahun 2010 sebesar 33,5\% meningkat menjadi 38,5\% pada tahun 2013. Enam belas provinsi dengan prevalensi risiko Kekurangan Energi Kronis (KEK) diatas nasional, yaitu Kalimantan Tengah, Jawa Timur, Banten, Kalimantan Selatan, Aceh, DI Yogyakarta, Nusa Tenggara Barat, Sulawesi Selatan, Sulawesi Tengah, Maluku Utara, Sulawesi Tenggara, Sulawesi Barat, Papua Barat, Maluku, Papua dan Nusa Tenggara Timur. Dari data yang diperoleh dari Dinas Kesehatan Kota Tidore Kepulauan Prevalensi KEK tertinggi berada di Puskesmas Tosa dari tahun 2015-2017 yaitu sebanayak 68 Kasus sedangkan yang terendah prevalensi KEK berada di Puskesmas Soasio yaitu sebanyak 22 dari tahun 2015-2017.

Berdasarkan data yang diperoleh di Wilayah Kerja Puskesmas Tosa Tahun 2015 jumlah kasus Kekurangan Energi Kronis (KEK) sebanyak 21 kasus atau 30,88\%, pada tahun 2016 Kekurangan Energi Kronis (KEK) meningkat sebanyak 27 kasus atau 39,71\%, sedangkan di tahun 2017 jumlah kasus Kekurangan Energi Kronis (KEK) menurun sebanyak 20 kasus atau 29,41\%. Data tersebut mengalami peningkatan 8,83\% dari tahun 2015 ke tahun 2016 dan penurunan kasus Kekurangan Energi Kronis (KEK) di Tahun 2016 ke Tahun 2017 sebanyak 10,3\%. Sedangkan pada Tahun 2018 Jumlah Kekurangan Energi Kronis (KEK) dari bulan Januari-Agustus yaitu berjumlah 68 kasus atau 44\%. (Data sekunder 2015-2018 di Puskesmas Tosa Kota Tidore Kepulauan). Sehingga penelitian bertujuan untuk mengetahui hubungan antara asupan makanan (zat gizi makro $\mathrm{KH}$, Protein dan lemak), pengetahuan ibu, pendapatan keluarga, usia ibu hamil dan jarak kelahiran dengan Kejadian Kurang Energi Kronik (KEK) pada Ibu hamil di Puskesmas Tosa,Kota Tidore Kepulauan.

\section{METODE PENELITIAN}

Jenis penelitian yang digunakan adalah survey analitik. dengan pendekatan cross sectional yaitu penelitian untuk mempelajari dinamika korelasi antara faktor-faktor risiko dengan efek, dengan cara pendekatan, observasi atau pengumpulan data sekaligus pada suatu saat (point time approach). Penelitian ini telah dilaksanakan pada bulan Oktober-November 2018 bertempat di Puskesmas Tosa Kota Tidore Kepulauan.

Populasi penelitian adalah seluruh ibu hamil yang pernah melakukan pemeriksaan di Puskesmas Tosa pada bulan Januari-September 2018, yaitu sebanyak 165 orang. Sedangkan Sampel dalam penelitian ini adalah sebagian dari populasi yang diharapkan dapat mewakili representatif populasi dengan memenuhi Kriteria inklusi yaitu :

a. Berdomisili tetap di Wilayah Kerja Puskesmas Tosa Kota Tidore Kepulauan.

b. Siap diwawancarai

c. Ibu Hamil yang pernah melahirkan sebelumnya (masuk pada kehamilan ke 2, dst).

Teknik pengambilan sampel secara total sampling yaitu 54 orang ibu hamil yang sudah pernah melahirkan di Puskesmas Tosa.

\subsection{Pengumpulan Data}

\section{a. Data primer}

Data primer adalah data yang diperoleh dari hasil survei langsung melalui wawancara menggunakan kuesioner asupan makanan dengan bantuan foto makanan yang didapat dengan Food Recall 2x24 jam dan pengukuran Lila pada Ibu Hamil dengan menggunakan Pita Lila dengan bantuan Bidan Desa.

\section{b. Data Sekunder}

Data yang diperoleh dari Dinas Kesehatan Kota Tidore Kepulauan dan Puskesmas Tosa. 


\subsection{Pengolahan dan Analisis Data}

Setelah data terkumpul, pengolahan data dilakukan melalui 4 tahap yaitu editing,coding, tabulating, cleaning dan analisis dengan menggunakan aplikasi SPSS dan Nutrisurvey.

a. Analisis Univariat, Analisis univariat dilakukan untuk menggambarkan distribusi frekuensi masingmasing variabel baik variabel bebas, variabel terikat dan distribusi frekuensi setiap variabel.

b. Analisis Nutrisurvey, Untuk menganalisis zat gizi (Energi, Protein, Lemak). maka digunakan aplikasi Nutrisurvey dan hasilnya dientry ke SPSS.

c. Analisis Bivariat, Untuk menguji hipotesis faktor-faktor kekurangan energi kronis (KEK) pada ibu hamil dengan pertimbangan tujuan dan jenis penelitian serta

memperhatikan skala data masing-masing variabel maka digunakan analisis statistik chi square dengan taraf nyata $\mathrm{p}=0,05$. Jika $\mathrm{p}<0,05$ berarti ada hubungan, dan bila $\mathrm{p}>0,05$ berarti tidak ada hubungan.

\subsection{Penyajian Data}

Data yang telah di olah dan dianalisis akan disajikan dalam bentuk table disertai dengan penjelasanya.

\section{HASIL DAN PEMBAHASAN}

\subsection{Hasil}

\section{Analisis Univariat}

\section{a. Distribusi Umur}

Tabel 1. Distribusi Karakteristik Responden Berdasarkan Umur di Wilayah Kerja PKM Tosa Kota Tidore Kepulauan Tahun 2018

\begin{tabular}{ccc}
\hline Umur Tahun & $\mathbf{n}$ & Persentase \\
\hline$(>34)$ & 6 & 11,1 \\
$(20-34)$ & 48 & 88,9 \\
\hline Total & $\mathbf{5 4}$ & $\mathbf{1 0 0 , 0}$ \\
\hline
\end{tabular}

Sumber : Data Primer, 2018

Tabel 1 diperoleh bahwa distribusi umur yang beresiko tinggi (umur $>34$ tahun) saat hamil yaitu sebanyak 6 responden $(11,1 \%$ ) sedangkan umur yang beresiko rendah (umur 20- 34 tahun) saat hamil sebanyak 48 responden $(88,9 \%)$.

\section{b. istribusi Pekerjaan}

Tabel 2. Distribusi Karakteristik Responden Berdasarkan Pekerjaan di Wilayah Kerja PKM Tosa Kota Tidore Kepulauan Tahun 2018

\begin{tabular}{lcc}
\hline \multicolumn{1}{c}{ Pekerjaan } & n & Persentase \\
\hline PNS & 2 & 3,7 \\
Pegawai swasta & 2 & 3,7 \\
Wiraswata & 7 & 13,0 \\
IRT & 43 & 79,6 \\
\hline Total & $\mathbf{5 4}$ & $\mathbf{1 0 0 , 0}$ \\
\hline Sumber $:$ Data Primer, 2018 &
\end{tabular}

Tabel 2 dapat diperoleh bahwa distribusi pekerjaan responden tertinggi yaitu IRT sebanyak 43 responden $(79,6 \%)$ dan wiraswasta sebanyak 7 responden $(13,0 \%)$ sedangkan distribusi terendah yaitu PNS dan pegawai swasta sebanyak 2 responden $(3,7 \%)$.

\section{c. Distribusi Pendidikan}

Tabel 3 dapat dijelaskan bahwa dari 54 responden diperoleh distribusi tertinggi yaitu responden yang tamat SD sebanyak 32 responden $(59,3 \%)$ dan PT sebanyak 4 responden $(7,4 \%)$ SLTA sebanyak 5 responden $(9,3 \%)$ SLTP sebanyak 12 responden $(22,2 \%)$ sedangkan distribusi terendah yaitu responden yang tidak sekolah sebanyak 1 responden $(1,9 \%)$. 
Tabel 3. Distribusi Karakteristik Responden Berdasarkan Pendidikan di Wilayah Kerja PKM Tosa Kota Tidore Kepulauan Tahun 2018

\begin{tabular}{lcc}
\hline \multicolumn{1}{c}{ Pendidikan } & n & Persentase \\
\hline Tidak sekolah & 1 & 1,9 \\
SD & 32 & 59,3 \\
SLTP & 12 & 22,2 \\
SLTA & 5 & 9,3 \\
PT & 4 & 7,4 \\
\hline \multicolumn{2}{c}{ Total } & $\mathbf{5 4}$
\end{tabular}

\section{d. Distribusi Usia kehamilan}

Tabel 4. Distribusi Karakteristik Responden Berdasarkan Usia Ibu Hamil di Wilayah Kerja PKM Tosa Kota Tidore Kepulauan Tahun 2018

\begin{tabular}{ccc}
\hline Usia kehamilan & n & Persentase \\
\hline Trimester 1 & 30 & 55,6 \\
Trimester 2 & 10 & 18,5 \\
Trimester 3 & 14 & 25,9 \\
\hline Total & $\mathbf{5 4}$ & $\mathbf{1 0 0 , 0}$
\end{tabular}

Tabel 4 diperoleh distribusi usia kehamilan terbanyak yaitu pada trimester 1 sebanyak 30 responden $(55,6 \%)$ dan trimester 3 sebanyak 14 responden $(25,9)$ sedangkan distribusi terendah yaitu pada trimester 2 sebanyak 10 responden $(18,5 \%)$.

\section{e. istribusi Asupan energi}

Tabel 5. Distribusi Karakteristik Responden Berdasarkan Asupan Energi di Wilayah Kerja PKM Tosa Kota Tidore Kepulauan Tahun 2018

\begin{tabular}{ccc}
\hline Asupan Energi & n & Persentase \\
\hline asupan baik & 9 & 16,7 \\
asupan kurang & 45 & 83,3 \\
\hline Total & $\mathbf{5 4}$ & $\mathbf{1 0 0 , 0}$ \\
\hline
\end{tabular}

Sumber : Data Primer 2018

Tabel 5 diperoleh distribusi asupan energi kurang yaitu sebanyak 45 responden $(83,3 \%)$ sedangkan distribusi asupan energi baik yaitu sebanyak 9 responden (16,7\%).

\section{f. Distribusi Asupan Protein}

Tabel 6. Distribusi Karakteristik Responden Berdasarkan Asupan Protein di Wilayah Kerja PKM Tosa Kota Tidore Kepulauan Tahun 2018

\begin{tabular}{ccc}
\hline Asupan Protein & Frekuensi & Persentase \\
\hline asupan baik & 25 & 46,3 \\
asupan kurang & 29 & 53,7 \\
\hline Total & $\mathbf{5 4}$ & $\mathbf{1 0 0 , 0}$
\end{tabular}

Sumber : Data Primer, 2018

Tabel 6 diperoleh distribusi asupan protein kurang sebanyak 29 responden (53,7\%) sedangkan distribusi asupan protein baik sebanyak 25 responden (46,3\%).

\section{g. Distribusi Asupan Lemak}

Tabel 7 menginformasikan bahwa distribusi asupan Lemak kurang sebanyak 45 responden $(83,3 \%)$ sedangkan distribusi asupan lemak baik sebanyak 9 responden $(16,7 \%)$. 
Tabel 7. Distribusi Karakteristik Responden Berdasarkan Asupan Lemak di Wilayah Kerja PKM Tosa Kota Tidore Kepulauan Tahun 2018

\begin{tabular}{ccc}
\hline Asupan Lemak & n & Persentase \\
\hline asupan baik & 9 & 16,7 \\
asupan kurang & 45 & 83.3 \\
\hline Total & $\mathbf{5 4}$ & $\mathbf{1 0 0 , 0}$
\end{tabular}

\section{h. Distribusi Pengetahuan}

Tabel 8. Distribusi Karakteristik Responden Berdasarkan pengetahuan di Wilayah Kerja PKM Tosa Kota Tidore Kepulauan Tahun 2018

\begin{tabular}{ccc}
\hline Pengetahuan & n & Persentase \\
\hline Baik & 33 & 61,1 \\
Kurang & 21 & 38,9 \\
\hline Jumlah & $\mathbf{5 4}$ & $\mathbf{1 0 0 , 0}$
\end{tabular}

Tabel 8 diperoleh distribusi pengetahuan kurang sebanyak 21 responden $(38,9)$ sedangkan responden dengan pengetahuan baik sebanyak 33 responden $(61,1 \%)$.

\section{i. Distribusi Pendapatan keluarga}

Tabel 9. Distribusi Karakteristik Responden Berdasarkan Pendapatan Keluarga di Wilayah Kerja PKM Tosa Kota Tidore Kepulauan Tahun 2018

\begin{tabular}{ccc}
\hline Pendapatan keluarga & $\mathbf{n}$ & Persentase \\
\hline$\geq 2.222 .000$ & 11 & 20,4 \\
$<2.222 .000$ & 43 & 79,6 \\
\hline Total & $\mathbf{5 4}$ & $\mathbf{1 0 0 , 0}$ \\
\hline Sumber : Data Primer, 2018 & &
\end{tabular}

Tabel 9 dapat diperoleh distribusi responden berpendapatan rendah yaitu $<\mathrm{Rp} 2.222 .000$ sejumlah 43 responden $(79,6 \%)$ sedangkan distribusi berpendapatan tinggi yaitu $\geq \mathrm{Rp}$ 2.222.000 sebanyak 11 responden $(20,4 \%)$.

\section{j. Distribusi Jarak kelahiran}

Tabel 10. Distribusi Karakteristik Responden Berdasarkan Jarak Kelahiran di Wilayah Kerja PKM Tosa Kota Tidore Kepulauan Tahun 2018

\begin{tabular}{lcc}
\hline \multicolumn{1}{c}{ Jarak kelahiran } & n & Persentase \\
\hline Resiko rendah & 23 & 42,6 \\
Resiko tinggi & 31 & 57,4 \\
\hline \multicolumn{1}{c}{ Total } & $\mathbf{5 4}$ & $\mathbf{1 0 0 , 0}$ \\
\hline Sumber : Data Primer 2018 & &
\end{tabular}

Tabel 10 dapat dijelaskan bahwa dari 54 responden diperoleh distribusi Jarak kelahiran resiko tinggi yaitu 31 responden $(57,4 \%)$ sedangkan distribusi jarak kelahiran resiko rendah sebanyak 23 responden $(42,6 \%)$.

\section{k. Distribusi LILA ibu hamil}

Tabel 11. Distribusi Karakteristik Responden Berdasarkan LILA Ibu Hamil di Wilayah Kerja PKM Tosa Kota Tidore Kepulauan Tahun 2018

\begin{tabular}{ccc}
\hline LILA & Frekuensi & Persentase \\
\hline Normal & 25 & 46,3 \\
KEK & 29 & 53,7 \\
\hline Total & $\mathbf{5 4}$ & $\mathbf{1 0 0 , 0}$ \\
\hline
\end{tabular}

Sumber : Data Primer, 2018 
Tabel 11 diperoleh distribusi LILA ibu hamil yang menderita KEK sebanyak 29 responden $(53,7 \%)$ sedangkan distribusi LILA ibu hamil normal sebanyak 25 (46,3\%).

\section{Distribusi rerata Zat gizi (Energi, Protein dan Lemak)}

Tabel 12. Rata-rata zat gizi (energi, protein dan lemak) Berdasarkan LILA Ibu Hamil di Wilayah Kerja PKM Tosa Kota Tidore Kepulauan Tahun 2018

\begin{tabular}{cccc}
\hline Asupan Zat Gizi & Total & n & Rata-rata \\
\hline Energi & $53.106,6$ & 54 & 983,4 \\
Protein & $2.159,8$ & 54 & 39,9 \\
Lemak & 1.628 & 54 & 30,1 \\
\hline Total & $\mathbf{5 6 . 8 9 4 , 4}$ & $\mathbf{1 6 2}$ & $\mathbf{1 , 0 5 3 , 4}$ \\
\hline
\end{tabular}

Sumber : Data Primer ,2018

Tabel 12 dapat dijelaskan bahwa dari 54 responden, Rata-rata asupan zat gizi energi sebanyak 983,4 kkal; protein sebanyak 39,9 gram dan lemak sebanyak 30,1 gr.

\subsection{Analisis Bivariat}

\section{a. Analisis Asupan energi}

Tabel 13. Analisis Hubungan KEK pada Ibu Hamil denganAsupan Energi di Wilayah Kerja PKM Tosa Kota Tidore Kepulauan Tahun 2018

\begin{tabular}{lccccccc}
\hline \multirow{2}{*}{$\begin{array}{c}\text { Asupan } \\
\text { Energi }\end{array}$} & \multicolumn{4}{c}{ Ibu Hamil } & \multicolumn{2}{c}{ Total } & \multirow{2}{*}{ P Value } \\
\cline { 2 - 6 } & $\boldsymbol{n}$ & $\boldsymbol{\%}$ & $\boldsymbol{n}$ & $\boldsymbol{\%}$ & $\boldsymbol{n}$ & $\%$ & \\
\hline Asupan Baik & 8 & 14,8 & 1 & 1,9 & 9 & 16,7 & \\
Asupan kurang & 17 & 31,5 & 28 & 51,9 & 45 & 83,3 & 0,01 \\
\hline Total & $\mathbf{2 5}$ & $\mathbf{4 6 , 3}$ & $\mathbf{2 9}$ & $\mathbf{5 3 , 7}$ & $\mathbf{5 4}$ & $\mathbf{1 0 0}$ & \\
\hline
\end{tabular}

Sumber : Data Primer , 2018

Tabel 13 diatas, dapat dilihat bahwa dari 54 responden dari faktor asupan energi yang mempunyai asupan energi kurang sebanyak 45 responden, pada kelompok normal sebanyak 17 responden $(31,5 \%)$ dan sisanya 28 responden $(51,9 \%)$ pada kelompok KEK yang merupakan distribusi tertinggi, sedangkan asupan energi yang mempunyai asupan baik terdapat 9 responden, pada kelompok normal sebanyak 8 responden $(14,8 \%)$ dan sisanya 1 responden $(1,9 \%)$ pada kelompok KEK yang merupakan distribusi terendah.

\section{b. Analisis Asupan protein}

Analisis hubungan antara asupan protein dengan KEK pada ibu hamil dapat dilihat pada Tabel 14.

Tabel 14. Analisis Hubungan KEK pada Ibu Hamil dengan Asupan Protein di Wilayah Kerja PKM Tosa Kota Tidore Kepulauan Tahun 2018

\begin{tabular}{|c|c|c|c|c|c|c|c|}
\hline \multirow{3}{*}{ Asupan Protein } & \multicolumn{4}{|c|}{ Ibu Hamil } & \multirow{2}{*}{\multicolumn{2}{|c|}{ Total }} & \multirow{3}{*}{$P$ Value } \\
\hline & \multicolumn{2}{|c|}{ Normal } & \multicolumn{2}{|c|}{ KEK } & & & \\
\hline & $n$ & $\%$ & $n$ & $\%$ & $n$ & $\%$ & \\
\hline Asupan Baik & 14 & 25,9 & 11 & 20,4 & 25 & 46,3 & \multirow{3}{*}{0,29} \\
\hline Asupan kurang & 11 & 20,4 & 18 & 33,3 & 29 & 53,7 & \\
\hline Total & 25 & 46,3 & 29 & 53,7 & 54 & 100 & \\
\hline
\end{tabular}

Sumber : Data Primer, 2018

Tabel 14 diatas, dapat dilihat bahwa dari 54 responden dari faktor asupan proteinyang mempunyai asupan protein kurang sebanyak 29 responden, pada kelompok normal sebanyak 11 responden $(20,4 \%)$ dan sisanya 18 responden $(33,3 \%)$ pada kelompok KEK yang merupakan distribusi tertinggi, sedangkan asupan protein yang mempunyai asupan baik terdapat 25 responden, pada kelompok normal sebanyak 14 responden $(25,9 \%)$ dan sisanya 11 responden $(20,4 \%)$ pada kelompok KEK yang merupakan distribusi terendah. 


\section{c. Analisis Asupan Lemak}

Tabel 15. Analisis hubungan KEK pada ibu hamil dengan asupan lemak di Wilayah Kerja PKM Tosa Kota Tidore Kepulauan Tahun 2018

\begin{tabular}{|c|c|c|c|c|c|c|c|}
\hline \multirow{3}{*}{ Asupan Lemak } & \multicolumn{4}{|c|}{ Ibu Hamil } & \multirow{2}{*}{\multicolumn{2}{|c|}{ Total }} & \multirow{2}{*}{ P Value } \\
\hline & \multicolumn{2}{|c|}{ Normal } & \multicolumn{2}{|c|}{ KEK } & & & \\
\hline & $n$ & $\%$ & $n$ & $\%$ & $n$ & $\%$ & \multirow{4}{*}{0,08} \\
\hline Asupan Baik & 7 & 13 & 2 & 3,7 & 9 & 16,7 & \\
\hline Asupan kurang & 18 & 33,3 & 27 & 50 & 45 & 83,3 & \\
\hline Total & 25 & 46,3 & 29 & 53,7 & 54 & 100 & \\
\hline
\end{tabular}

Sumber : Data Primer, 2018

Tabel 15 diatas, dapat dilihat bahwa dari 54 responden dari faktor asupan Lemakyang mempunyai asupan lemak kurang sebanyak 45 responden, pada kelompok normal sebanyak 18 responden $(33,3 \%)$ dan sisanya 27 responden $(50,0 \%)$ pada kelompok KEK yang merupakan distribusi tertinggi, sedangkan asupan Lemak yang mempunyai asupan baik terdapat 9 responden, pada kelompok normal sebanyak 7 responden $(13,0 \%)$ dan sisanya 2 responden $(3,7 \%)$ pada kelompok KEK yang merupakan distribusi terendah.

\section{d. Analisis Pengetahuan}

Tabel 16. Analisis hubungan KEK pada ibu hamil dengan pengetahuan di Wilayah Kerja PKM Tosa Kota Tidore Kepulauan Tahun 2018

\begin{tabular}{|c|c|c|c|c|c|c|c|}
\hline \multirow{3}{*}{ Pengetahuan } & \multicolumn{4}{|c|}{ Ibu Hamil } & \multirow{2}{*}{\multicolumn{2}{|c|}{ Total }} & \multirow{2}{*}{ P Value } \\
\hline & \multicolumn{2}{|c|}{ Normal } & \multicolumn{2}{|c|}{ KEK } & & & \\
\hline & $n$ & $\%$ & $n$ & $\%$ & $n$ & $\%$ & \multirow{4}{*}{0,32} \\
\hline Baik & 13 & 24,1 & 20 & 37,0 & 33 & 611 & \\
\hline Kurang & 12 & 22,2 & 9 & 16,7 & 21 & 38,9 & \\
\hline Total & 25 & 46,3 & 29 & 53,7 & 54 & 100 & \\
\hline
\end{tabular}

Sumber : Data Primer , 2018

Tabel 16 diatas, dapat dilihat bahwa dari 54 responden dari faktor pengetahuanyang mempunyai pengetahuan kurang sebanyak 21 responden, pada kelompok normal sebanyak 12 responden $(22,2 \%)$ dan sisanya 9 responden $(16,7 \%)$ pada kelompok KEK, yang merupakan distribusi terendah sedangkan yang mempunyai pengetahuan baik terdapat 33 responden, pada kelompok normal sebanyak 13 responden $(24,1 \%)$ dan sisanya 20 responden $(37,0 \%)$ pada kelompok KEK yang merupakan distribusi tertinggi.

\section{e. Analisis Pendapatan Keluarga}

Tabel 17. Analisis hubungan KEK pada ibu hamil dengan pendapatan keluarga di Wilayah Kerja PKM Tosa Kota TidoreKepulauan Tahun 2018

\begin{tabular}{lccccccc}
\hline \multirow{2}{*}{$\begin{array}{l}\text { Pendapatan } \\
\text { keluarga }\end{array}$} & \multicolumn{9}{c}{ Normal } & KEK & \multicolumn{3}{c}{ Total } & \multirow{2}{*}{ P Value } \\
\cline { 2 - 7 } & $\boldsymbol{n}$ & $\boldsymbol{n}$ & $\boldsymbol{n}$ & $\boldsymbol{\%}$ & $\boldsymbol{n}$ & $\boldsymbol{\%}$ & \\
\cline { 2 - 7 } Tinggi & 10 & 18,5 & 1 & 1,9 & 11 & 20,4 & \multirow{2}{*}{0,00} \\
Rendah & 15 & 27,8 & 28 & 51,9 & 43 & 79,6 & \\
\hline Total & $\mathbf{2 5}$ & $\mathbf{4 6 , 3}$ & $\mathbf{2 9}$ & $\mathbf{5 3 , 7}$ & $\mathbf{5 4}$ & $\mathbf{1 0 0}$ & \\
\hline
\end{tabular}

Sumber : Data Primer , 2018

Tabel 17 diatas, dapat dilihat bahwa dari 54 responden dari faktor pendapatan keluarga yang mempunyai pendapatan keluarga rendah sebanyak 43 responden, pada kelompok normal sebanyak 15 responden $(27,8 \%)$ dan sisanya 28 responden $(51,9 \%)$ pada kelompok KEK yang merupakan distribusi tertinggi, sedangkan pendapatan yang mempunyai pendapatan tinggi terdapat 11 responden, pada kelompok normal sebanyak 10 responden $(18,5 \%)$ dan sisanya 1 responden $(1,9 \%)$ pada kelompok KEK yang merupakan distribusi terendah. 


\section{f. Analisis Usia Ibu Hamil}

Tabel 18. Analisis hubungan KEK pada Ibu Hamil dengan Usia Ibu Hamil di Wilayah Kerja PKM Tosa Kota Tidore Kepulauan Tahun 2018

\begin{tabular}{cccccccc}
\hline & \multicolumn{4}{c}{ Ibu Hamil } & \multirow{2}{*}{ Total } & \multirow{2}{*}{ P Value } \\
\cline { 2 - 6 } Usia Ibu Hamil & \multicolumn{2}{c}{ Normal } & \multicolumn{2}{c}{ KEK } & & & \\
\cline { 2 - 6 } & $\boldsymbol{n}$ & $\boldsymbol{\%}$ & $\boldsymbol{n}$ & $\boldsymbol{\%}$ & $\boldsymbol{n}$ & $\boldsymbol{\%}$ & \\
\hline Resiko Tinggi & 3 & 5,6 & 3 & 5,6 & 6 & 11,1 & \multirow{2}{*}{1,00} \\
Resiko Rendah & 22 & 40,7 & 26 & 48,1 & 48 & 88,9 & \\
\hline Total & $\mathbf{2 5}$ & $\mathbf{4 6 , 3}$ & $\mathbf{2 9}$ & $\mathbf{5 3 , 7}$ & $\mathbf{5 4}$ & $\mathbf{1 0 0}$ & \\
\hline
\end{tabular}

Sumber : Data Primer , 2018

Tabel 18 diatas, dapat dilihat bahwa dari 54 responden dari faktor usia ibu hamil yang mempunyai usia ibu hamil resiko rendah sebanyak 48 responden, pada kelompok normal sebanyak 22 responden $(40,7 \%)$ dan sisanya 26 responden $(48,1 \%)$ pada kelompok KEK yang merupakan distribusi tertinggi, sedangkan usia ibu hamil yang mempunyai resiko tinggi terdapat 6 responden yang mempunyai resiko tinggi terdapat 3 responden $(5,6 \%)$ pada kelompok normal dan sisanya 3 responden $(5,6 \%)$ pada kelompok KEK yang merupakan distribusi terendah.

\section{g. Analisis Jarak Kelahiran}

Tabel 19. Analisis hubungan KEK pada ibu hamil dengan Jarak Kelahiran di Wilayah Kerja PKM Tosa Kota Tidore Kepulauan Tahun 2018

\begin{tabular}{|c|c|c|c|c|c|c|c|}
\hline \multirow{3}{*}{ Jarak Kelahiran } & \multicolumn{4}{|c|}{ Ibu Hamil } & \multirow{2}{*}{\multicolumn{2}{|c|}{ Total }} & \multirow{3}{*}{$P$ Value } \\
\hline & \multicolumn{2}{|c|}{ Normal } & \multicolumn{2}{|c|}{ KEK } & & & \\
\hline & $n$ & $\%$ & $n$ & $\%$ & $n$ & $\%$ & \\
\hline Resiko Tinggi & 13 & 24,1 & 18 & 33,3 & 31 & 57,4 & \multirow{3}{*}{0,63} \\
\hline Resiko Rendah & 12 & 22,2 & 11 & 20,4 & 23 & 42,6 & \\
\hline Total & 25 & 46,3 & 29 & 53,7 & 54 & 100 & \\
\hline
\end{tabular}

Sumber : Data Primer, 2018

Tabel 19 diatas, dapat dilihat bahwa dari 54 responden dari faktor jarak kelahiran yang mempunyai jarak kelahiran resiko rendah sebanyak 23 responden, pada kelompok normal sebanyak 12 responden $(22,2 \%)$ dan sisanya 11 responden $(20,4 \%)$ pada kelompok KEK yang merupakan distribusi terendah, sedangkan jarak kelahiran yang mempunyai resiko tinggi terdapat 31 responden, yang mempunyai resiko tinggi terdapat 13 responden $(24,1 \%)$ pada kelompok normal dan sisanya 18 responden $(33,3 \%)$ pada kelompok KEK yang merupakan distribusi tertinggi.

\subsection{Pembahasan}

Kehamilan menyebabkan meningkatnya metabolisme energi, karena itu kebutuhan energi dan zat gizi lainnya meningkatnya selama kehamilan. Peningkatan energi dan zat gizi tersebut diperlukan untuk pertumbuhan dan perkembangan janin, pertambahan besar organ kandungan, perubahan komposisi dan metabolisme tubuh ibu. Bila status gizi ibu kurang maka ibu hamil akan mengalami masalah gizi kekurangan energi kronis (KEK) yang akan berdampak pada bayi yang dikandungnya (Zulhaida, 2014).

Kekurangan energi kronis (KEK) merupakan suatu kejadian ketidakseimbangan asupan makanan energi dan protein yang berlangsung menahun (Kronis) sehingga mengakibatkan timbulnya gangguan kesehatan pada ibu yang ditandai dengan Lingkar Lengan Atas (LILA) ibu hamil kurang dari $23,5 \mathrm{~cm}$ atau dibagian merah pita LILA yang mengindikasikan wanita tersebut menderita KEK (Arisman, 2015).

\section{a. Hubungan Asupan Energi dengan KEK pada Ibu Hamil}

Energi berfungsi sebagai zat tenaga untuk metabolisme, pertumbuhan, pengaturan suhu dan kegiatan fisik. Kelebihan energi disimpan dalam bentuk glikogen sebagai cadangan energi jangka pendek dan dalam bentuk lemak sebagai cadangan jangka panjang, Kebutuhan akan energi pada trimester 1 meningkat secara minimal. Selain itu, sepanang trimester ll dan lll, kebutuhan akan terus membesar sampai pada akhir kehamilan. 
Dari hasil penelitian ini berdasarkan hasil recall asupan makanan yang dilakukan diperoleh bahwa banyak ibu hamil yang mempunyai asupan energi kurang yaitu sebanyak 45 responden $(83,3 \%)$. sedangkan asupan baik sebanyak 9 responden $(16,7 \%)$. Banyaknya asupan energi yang kurang dikonsumsi Karena banyak ibu hamil yang kurang mengkonsumsi makanan yang mengandung karbohidrat, lemak dan protein seperti nasi, ubi-ubian, ikan, daging dan sayuran. dan juga masih banyak ibu hamil yang mengkonsumsi makanan tidak sesuai dengan jumlah/porsi yang dibutuhkan saat hamil terutama makanan yang mengandung tinggi protein seperti daging dan juga sayuran yang sangat berkontribusi besar dalam pertumbuhan dan perkembangan ibu dan janin yang dikandungnya.

Penelitian ini tidak sejalan dengan penelitian Juada, (2014) berdasarkan hasil penelitiannya tentang tingkat asupan makanan energi, protein dan lemak dengan kejadian KEK diperoleh hasil uji statistik nilai $p=0,124$, yang artinya tidak ada hubungan yang signifikan antara tingkat asupan energi dengan KEK pada ibu hamil.

\section{b. Hubungan Asupan Protein dengan KEK pada Ibu Hamil}

Protein adalah sumber makanan zat gizi yang berfungsi untuk proses pertumbuhan dan perkembangan jaringan tubuh protein bisa didapat dari nabati maupun hewani. Sumber hewani seperti daging tak berlemak, ikan, telur, susu. Sedangkan sumber nabati seperti tahu, tempe dan kacang-kacangan Protein digunakan untuk: pembentukan jaringan baru baik plasenta dan janin, pertumbuhan dan diferensiasi sel, pembentukan cadangan darah dan Persiapan masa menyusui.

Dari hasil penelitian ini berdasarkan hasil recall asupan makanan yang dilakukan diperoleh bahwa banyak ibu hamil yang mempunyai asupan protein kurang yaitu sebanyak 29 responden (53,7\%), sedangkan ibu hamil yang mempunyai asupan energi baik yaitu 25 responden (46,3\%). Kurangnya konsumsi protein oleh ibu hamil karena banyak ibu hamil yang kurang mengkonsumsi makanan yang mengandung protein hewani seperti daging dan juga protein nabati seperti tahu, tempe dan kacang-kacangan, banyak ibu hamil yang hanya mengkonsumsi ikan tetapi ikan yang dikonsumsi tidak memenuhi standar AKG yang dibutuhkan saat hamil, juga banyak ibu yang mempunyai usia kehamilan pada trimester 1-3 sehingga masih mengalami mual dan muntah sehingga banyak makanan yang dikonsumsi dikeluarkan kembali dan kadang juga dari mereka tidak mempunyai napsu makan.

Penelitian ini tidak sejalan dengan penelitian Juada, (2014) berdasarkan hasil penelitiannya tentang tingkat asupan makanan energi, protein dan lemak dengan kejadian KEK diperoleh hasil uji statistik nilai $p=0,149$, yang artinya tidak ada hubungan yang signifikan antara tingkat asupan protein dengan KEK pada ibu hamil.

Penelitian ini sejalan dengan penelitian Jima dkk, (2016) berdasarkan hasil penelitiannya tentang prevalensi kekurangan energi kronis di District Adama (Ethiopia Timur) berdasarkan hasil penelitian yang dilakukan diperoleh bahwa ada hubungan yang signifikan antara asupan makanan protein dengan Kejadian KEK dengan hasil statistik $\mathrm{p}=0,032$, hal ini mengindikasikan bahwa ada hubungan antara kejadian KEK dengan asupan makanan.

\section{c. Hubungan Asupan Lemak dengan KEK pada Ibu Hamil}

Lemak adalah sumber energi yang efisien dan berfungsi menjaga kebugaran, selain bermanfaat sebagai bantalan organ-organ vital, lemak juga berfungsi untuk mempertahankan suhu tubuh normal, lemak juga merupakan nutrisi esensial untuk fungsi otak, selain sumber tenaga, lemak juga berguna untuk mularutkan vitamin A, D , E, K sehingga dapat diserap oleh dinding usus (Milda, 2016).

Dari hasil penelitian ini berdasarkan hasil recall asupan makanan yang dilakukan diperoleh bahwa banyak ibu hamil yang kurang mengkonsumsi makanan yang mengandung asupan lemak yaitu sebanyak 45 responden (83,3\%), sedangkan ibu hamil yang mempunyai asupan lemak yang baik sebanyak 9 responden (16,7\%), banyaknya asupan lemak yang kurang dikonsumsi, karena banyak ibu hamil yang kurang konsumsi makanan mengandung lemak seperti ikan, daging, tahu dan tempe. Sehingga untuk kecukupan Lemak pada ibu hamil ini masih sangat kurang, banyak dari mereka yang memilih untuk mengkonsumsi ikan dibandingkan daging, tahu, tempe dan jenis makanan mengandung lemak lainnya.

Penelitian ini sejalan dengan penelitian Juada, (2014) berdasarkan hasil penelitiannya tentang tingkat asupan makanan energi, protein dan lemak dengan kejadian KEK diperoleh hasil uji statistik nilai $\mathrm{p}=0,449$, yang artinya tidak ada hubungan yang signifikan antara tingkat asupan lemak dengan KEK pada ibu hamil. 


\section{d. Hubungan Pengetahuan dengan KEK pada Ibu Hamil}

Pengetahuan merupakan segala sesuatu yang berada di dalam maupun diluar lingkungan manusia, baik yang sudah diketahui maupun yang belum diketahui, pengetahuan masyarakat terutama ibu hamil akan mengkonsumsi makanan bergizi merupakan satu langkah awal dalam rangka meningkatkan status kesehatan secara optimal (Jumirat,dkk, 2000).

Dari hasil penelitian ini berdasarkan hasil pengisian koesoner yang dilakukan oleh ibu hamil banyak dari mereka yang mempunyai pengetahuan yang baik yaitu sebanyak 33 responden (61,1\%), sedangkan yang mempunyai pengetahuan kurang yaitu 21 responden $(38,9 \%)$, meskipun banyak ibu hamil yang mempunyai asupan baik, tetapi tidak didukung oleh tindakan atau implementasi yang dilakukan dalam kehidupan sehari-hari, seperti konsumsi makanan yang bergizi dan seimbang saat hamil, karena banyak ibu hamil yang mempunyai pengetahuan yang kurang tentang bagaimana konsumsi makanan saat hamil dan apa saja yang perlu dilakukan agar ibu tidak menderita KEK saat hamil.

Penelitian ini tidak sejalan dengan penelitian Siti, (2014) berdasarkan hasil penelitiannya tentang hubungan pengetahuan terhadap kejadian KEK diperoleh hasil uji statistik nilai $p=0,049$, hal ini menunjukan bahwa ada pengaruh antara pengetahuan terhadap kejadian KEK.

Penelitian ini tidak sejalan dengan penelitian yang dilakukan Syafruddin, (2018) berdasarkan hasil penelitiannya tentang penentu kekurangan energi kronis pada ibu hamil maka diperoleh hasil statistik nilai $p=0,051$, hal ini menunjukan bahwa ada hubungan antara pengetahuan dengan kejadian KEK pada ibu hamil.

\section{e. Hubungan Pendapatan Keluarga dengan KEK pada Ibu Hamil}

pendapatan keluarga adalah jumlah penghasilan riil dari seluruh anggota rumah tangga yang disumbangkan untuk memenuhi kebutuhan bersama maupun perseorangan dalam rumah tangga, yang meliputi pendapatan formal, pendapatan informal dan pendapatan subsistem (Suhardjo,2003).

Dari hasil penelitian ini diperoleh bahwa banyak ibu hamil yang mempunyai pendapatan yang rendah yaitu sebanyak 43 responden $(79,6 \%)$, sedangkan ibu hamil yang mempunyai pendapatan tinggi yaitu 11 responden $(20,4 \%)$, banyaknya ibu hamil yang mempunyai pendapatan rendah, karena banyak mayoritas masyarakatnya petani yang hanya bergantung pada kebun dan hasil panen sehingga dapat mempengaruhi daya beli bahan pangan dalam rumah tangga.

Penelitian ini tidak sejalan dengan penelitian Suhariyati, (2016) berdasarkan hasil penelitiannya tentang Faktor yang Mempengaruhi Kejadian KEK Pada Ibu Hamil di Puskesmas Baturetno Kabupaten Wonogiri dari hasil uji statistik chi square didapat nilai $p=0,157(p<0,05)$ yang artinya Ho diterima dan Ha ditolak, sehingga tidak ada hubungan antara pendapatan keluarga dengan KEK pada ibu hamil.

\section{f. Hubungan Usia Ibu Hamil dengan KEK pada Ibu Hamil}

Usia atau umur Kelahiran merupakan salah satu faktor penting dalam proses kehamilan dan persalinan. Kehamilan pada ibu yang berumur terlalu muda menyebabkan kompetisi makanan antara janin dan ibu yang masih dalampertumbuhan. usia ibu hamil dibedakan atas dua golongan umur tepat melahirkan, yakni golongan usia berisiko dengan usia kurang dari 20 tahun dan lebih dari 34 tahun dan usia tidak berisiko yakni usia 21 tahun sampai 34 tahun (Mahirawati, 2014).

Dari hasil penelitian ini diperoleh bahwa banyak ibu hamil yang mempunyai resiko rendah saat hamil yaitu pada usia 20-34 tahun sebanyak 48 responden (88,9\%), sedangkan ibu hamil yang mempunyai resiko tinggi saat hamil yaitu pada usia $>34$ tahun sebanyak 6 responden $(11,1 \%)$, banyaknya ibu hamil yang mempunyai resiko rendah saat hamil, karena banyak dari mereka yang mempunyai usia saat hamil yaitu 20-34 tahun. sehingga hal ini mengindikasikan bahwa ibu akan mempunyai resiko rendah menderita KEK saat hamil.

Penelitian ini tidak sejalan dengan penelitian Laila, (2016) berdasarkan hasil penelitiannya tentang Faktor-faktor yang berhubungan dengan kejadian KEK pada ibu hamil di Puskesmas Belimbing Padang dari hasil uji statistik chi square didapat nilai $p=0,024(p<0,05)$ yang artinya Ha diterima dan Ho ditolak, sehingga terdapat hubungan usia dengan KEK pada ibu hamil.

\section{g. Hubungan Jarak Kelahiran dengan KEK pada Ibu Hamil}

Jarak kelahiran adalah tiap berapa tahun seorang ibu melahirkan. Ibu dikatakan terlalu sering melahirkan bila jaraknya kurang dari 2 tahun. Penelitian menunjukkan bahwa apabila keluarga dapat mengatur jarak antara kelahiran anaknya lebih dari 2 tahun maka anak akan memiliki probabilitas 
hidup lebih tinggi dan kondisi anaknya lebih sehat dibanding anak dengan jarak kelahiran dibawah dua tahun. (Siswanto A, 2004)

Dari hasil penelitian ini diperoleh bahwa masih banyak ibu hamil yang mempunyai jarak kelahiran yang terlalu dekat dan sangat beresiko tinggi yaitu sebanyak 31 responden $(57,4 \%)$ sedangkan yang beresiko rendah sebanyak 23 responden $(42,6 \%)$ banyaknya ibu hamil yang mempunyai resiko tinggi saat kelahiran dan sangat membahayakan kesehatan ibu, Karena dari segi fisiologi sistem organ tubuh masih dalam proses pemulihan dan juga masih dibutuhkan asupan makanan untuk menggantikan makanan yang hilang saat proses kelahiran, tetapi karena sudah hamil kembali maka akan terjadi kompetisi makanan antara ibui dan bayi yang dikandungnya dan sangat membahayakan kesehatan ibu, karena masih banyak ibu hamil yang masih mempunyai pemahaman yang minim tentang jarak kelahiran yang ideal.

Penelitian ini tidak sejalan dengan penelitian Sumarni, (2015) berdasarkan hasil penelitiannya tentang Faktor yang Mempengaruhi Kejadian KEK Pada Ibu Hamil di Puskesmas Baturetno Kabupaten Wonogiri dari hasil uji statistik chi square didapat nilai $\mathrm{p}=0,001(\mathrm{p}<0,05)$ yang artinya Ha diterima dan Ho ditolak, sehingga terdapat hubungan Jarak Kelahiran dengan KEK pada ibu hamil.

\section{PENUTUP}

Berdasarkan hasil penelitian yang telah dilakukan maka dapat disimpulkan:

1. Ada hubungan antara asupan energi dengan KEK pada ibu hamil di Puskesmas Tosa Kota Tidore Kepulauan dengan nilai $\mathrm{p}=0,01$, hal ini disebabkan karena asupan makanan energi sangat di butuhkan ibu pada waktu hamil.

2. Tidak ada hubungan antara asupan protein dengan KEK pada ibu hamil di Puskesmas Tosa Kota Tidore Kepulauan dengan nilai $\mathrm{p}=0,29$, hal ini disebabkan karena asupan makanan yang mengandung protein sangat di butuhkan ibu pada waktu hamil.

3. Tidak Ada hubungan antara asupan Lemak dengan KEK pada ibu hamil di Puskesmas Tosa Kota Tidore Kepulauan dengan nilai $\mathrm{p}=0,08$.

4. Tidak ada hubungan antara pengetahuan ibu dengan KEK pada ibu hamil di Puskesmas Tosa Kota Tidore Kepulauan dengan nilai $\mathrm{p}=0,32$

5. Ada hubungan antara Pendapatan keluarga dengan KEK pada ibu hamil di Puskesmas Tosa Kota Tidore Kepulauan dengan nilai $\mathrm{p}=0,03$, hal ini disebabkan karena apabila pendapatan kurang maka akan berpengaruh terhadap daya beli pangan.

6. Tidak Ada hubungan antara usia ibu hamil dengan KEK pada ibu hamil di Puskesmas Tosa Kota Tidore Kepulauan dengan nilai $\mathrm{p}=1,00$

7. Tidak Ada hubungan antara Jarak kelahiran dengan KEK pada ibu hamil di Puskesmas Tosa Kota Tidore Kepulauan dengan nilai $\mathrm{p}=0,63$

Bagi mereka yang menderita KEK pada saat hamil segera memperhatikan dan memperbaiki asupan makanan, lebih ditingkatkan lagi konsumsi energi dan protein agar supaya dapat tercukupi kebutuhan ibu dan bayi yang dikandungnya. Bagi keluarga yang mempunyai pendapatan rendah perlunya pemahaman tentang pentingnya persediaan makanan rumah tangga secara baik dengan melakukan diverifikasi pangan lokal dengan memanfaatkan lahan untuk menanam tanaman untuk menyediakan sumber makanan yang bergizi bagi keluarga.

\section{DAFTAR PUSTAKA}

Ahdaniar, A., Hasanudin,. Indar. H, 2014. Faktor Yang Berhubungan Dengan Kejadian Penyakit Rematik Pada Lansia Di Wilayah Puskesmas Kassi-Kassi Kota Makasar. Jurnal Ilmiah Kesehatan Diagnosa, Volume 4, Nomor 2, Tahun 2014. Online diakses pada tanggal: 15 Mei 2017

Aru W. S, 2007. Buku Ajar Ilmu Penyakit Dalam edisi 4. Jakarta: Fakultas Kedokteran Universitas Indonesia.

Bandiyah. S, 2009. Lanjut Usia dan Keperawatan Gerontik. Yogyakarta: Muha medika. 
Bawarodi. F, Rottie. J \& Malara. R, 2017. Faktor-faktor yang berhubungan dengan kekambuhan penyakit rematik di Wilayah Puskesmas Beo Kabupaten Talaud .e-journal Keperawatan (eKp) Volume 5 Nomor 1, Mei 2017.0nline. https://media.neliti.com/media/publications/ 114397-ID. diakses: 20 Mei 2017

DepKes. (2013). Pusat Data dan Informasi Profil Kesehatan Indonesia. Jakarta: Departemen Kesehatan RI

Jazmi, M. S (2016). Faktor Resiko Terjadinya Rematik Artritis Pada Lansia Diposiandu Wilayah Kerja Puskesmas II Baturaden. Online. diakses pada tanggal: 18 Mei 2017

Junaidi, 2012. Reumatik dan Asam Urat. Jakarta . BIP.

Nugroho.C, 2014. Hubungan Pengetahuan Lansia tentang Arthritis Reumatoid dengan upaya Penatalaksanaannya. Jurnal AKP Vol. 5 No. 2, 1 Juli - 31 Desember 2014, Online: ejournal.akperpamenang.ac.id/index.php/akp/article/download/96/80. Diakses: 20 Mei 2017

Smith, 2006. Penyakit Radang Sendi, Jakarta. Penerbit : Rineke Cipta.

Supariasa. 2012. Gizi Pada Lanjut Usia. Jakarta FKUI.

Susanto, A. (2013). Jumlah lansia Indoneisa Lima Besar terbanyak di Dunia. Online. (http://health.liputan6.com/read/541940/jumlah-lansia-indonesia-lima-besar-terbanyakdi-dunia. diakses pada tanggal 10 Mei 2017.

Stockslager. J. L, 2007. Buku Saku Asuhan Keperawatan Geriatrik edisi 2. Jakarta: EGC.

Syam. S, 2012. Faktor-faktor yang berhubungan dengan kejadian Rematik pada Lansia di Wilayah Kerja Puskesmas Mandiangin Tahun 2012. Jurnal Kesehatan Masyarakat STIKes Prima Nusantara Bukittinggi $\quad$ Vol.3 $\quad$ No.2 Juli 2012.online:http://ejurnal.stikesprimanusantara.ac.id/index.php/JKPN/article/viewFile/163 L128. Diakses: 10 September 2017.

Tamsuri. A, 2008. Riset keperawatan. Kediri: Pamenang press.

Putra, Agus Antara Iwayan. 2009. Faktor Faktor Yang Berhubungan Dengan Penyakit Rematik Pada Lansia Di RW06 Kelurahan Krukut Kec. Lima Depok. Online Http://Www.Library.Upnvj.Ac.Id/Index.Php . diakses pada tanggal: 15 Mei 2017 